\title{
MODERNIZATION, NATIONALISM AND THE ELITE: the Genesis of Brazilian jiu-jitsu, 1905-1920
}

\author{
José Cairus*
}

\begin{abstract}
This article is based on a chapter of my dissertation entitled The Gracie Clan and the Making of Brazilian Jiu Jitsu: National Identity, Performance and Culture, 1905-1993. It analyzes the introduction, creolization, popularization and globalization of the martial art known as Brazilian jiu-jitsu, by examining the trajectory of the principal agents of these events, the Gracie family who reinvented the Japanese martial art by creating a complex, ritualistic hyper-masculinized life style, forged from the clash between tradition and modernity embed in violence "made in Brazil." The article is divided in two sections in which I analyzed the introduction of Japanese jiu-jitsu as part of a turn-of- the-century global modernization. In the first part the narrative takes place in Rio de Janeiro in early twentieth century and examines the introduction of Japanese jiu-jitsu as modern school of physical education patronized by the military. This section is represented in the vignette "Round 1". In the second part the narrative shifted to the Amazon where a modern school of jiu-jitsu was established as a result of a transnational encounter between a troupe of Japanese martial artists and a Scottish-Brazilian family. This section is represented in the vignette "Round 2".
\end{abstract}

Keywords: Modernization. Identity. Nationalism. Race. Performance.

\section{Introduction}

This article begins by presenting snapshots of two violent confrontations in which practitioners of the Japanese martial art known as jiu-jitsu fought against those of the Brazilian Afro-diasporic martial art known as capoeira. It introduces debates about the adoption of jiu-jitsu, associated with the conflicting relationship between local and foreign cultures in Brazil. These events will reveal contradictory discourses on issues of modernization, race and identity. The first section of this chapter analyses jiu-jitsu's introduction to Brazil, from the early 1900s until World War I. It explains how the perception

\footnotetext{
* Doutorando em História pela York University - Toronto - Canadá. E-mail: cairus@rogers.com.
} 
of Japan as a model of modernization among members of the Brazilian elite facilitated jiujitsu's introduction. This section also describes how the military adopted jiu-jitsu in the wake of the Russo-Japanese War in 1904-1905. At the time, jiu-jitsu was showcased by Japanese martial artists trained in its pre-modern styles, who presented physical education drills for the military, non-lethal techniques for law enforcement agencies, and public entertainment for wider audiences. The adoption of jiu-jitsu by the military, however, found a strong opponent in Brazilian nationalism during its embryonic stage in the early 1900s. In the confrontation described in the first round, nationalism embodied by capoeira defeated modernization represented by Japanese jiu-jitsu.

The second section addresses jiu-jitsu's definitive introduction in the Brazilian Amazon during World War I, through to its continued dissemination with the Gracie family. It presents a transnational and dialectical relationship between different individuals and different historical forces. The encounter of the Japanese martial artist Mayeda Mitsuyo and the Scottish-Brazilian Gracie family in peripheral Brazil under peculiar circumstances must be seen in the context of the struggle by each party to retain, regain and perpetuate their status. Differently to the previous encounter in Rio de Janeiro, the modern jiu-jitsu represented by the Kodokan judo school and brought to Brazil by Mayeda Mitsuyo, combined technical improvements and philosophical modernity without loosing its quintessential, traditionalistic appeal. In a second round against capoeira, Japanese jiu-jitsu, or rather its modernized version represented by Kodokan judo, defeated nationalism, amidst the cosmopolitan atmosphere of the Brazilian Amazon and supported by the Gracies’ patrician ethos.

\section{Round 1: Japanese jiu-jitsu versus Brazilian capoeira, Rio de Janeiro's Belle Epoque, 1909}

On May 1, 1909 at the Concerto Avenida (Concert Avenue Theatre) in downtown Rio de Janeiro, an Afro-Brazilian capoeira player named Francisco Cyríaco (nicknamed “Old Monkey") and Japanese martial artist Sada Miako were about to fight the match of their lives. Cyríaco had been born 38 years earlier, among the sugar cane fields of northern Rio de Janeiro state, at a time when slavery still existed in Brazil. ${ }^{1}$ He worked carrying sacks of coffee in downtown Rio. In the violent streets of Rio de Janeiro’s belle époque, he had earned a reputation as a tough street fighter. His opponent, Sada Miako, had been hired by the Brazilian Navy to teach jiu-jitsu to its elite officer corps. Cyríaco, however, had support from the ranks of the progressive elite. He was informally "adopted" by the medical school 
students of the National Academy of Medicine in downtown Rio de Janeiro, who, emboldened by their enthusiastic nationalism, urged him to defend what they had started to regard as a Brazilian combat sport.

Sada Miako, on the other hand, like other Japanese martial artists sojourning in the West at the time, also performed public bouts. The fight had to overcome resistance from the authorities first, however. The public practice of capoeira was outlawed by the republican Criminal Code of $1890 .^{2}$ After insistent requests, the law was relaxed and the charismatic Cyríaco declared: "I am quite confident in my skills, if I have a shot, I will not disappoint you." He had to wear the traditional jiu-jitsu uniform (gi), a measure intended to make the Afro-Brazilian respectable and clean in order to better represent the national colors. Cyríaco himself later described the episode:

I went up there, saluted the Japanese and began my ginga. ${ }^{3}$ I sized him up, faked a slap and applied a leg sweep that had him off balance. But he stood. The crowd yelled: ‘Go for it Cyríaco!' I resumed my ginga leaning my body left and unleashed a rabo de arraia (stingray tail) that made him eat dust. I saluted the audience, gazed towards the man holding the clock, but the gringo refused to continue. ${ }^{4}$

Cyríaco cleverly avoided close combat that would favor the Japanese combatant. Instead he kept the latter off-balance by continuously performing capoeira's ginga. The Japanese fighter attempted to apply a jiu-jitsu technique called morote gari (double-leg takedown), but the capoeira practitioner struck first and applied a circular foot strike known as the stingray tail (rabo-de-arraia), which hit the Japanese fighter on the head; Sada was knocked down. The audience burst into cheers, and carried Cyríaco on their shoulders through the streets of the city center, crying: “Asia kneels to Brazil!” Local dailies reported a wave of patriotism in the wake of Cyríaco’s victory. Articles with numerous pictures highlighted the face-off between "a foreign martial art adopted by the Navy, against another, which despite being genuinely Brazilian, remained marginalized.” The press, reflecting the nationalistic mood, stated: “This was well done! It is evidence that we don’t need anything from outside: we have corn and beans. From abroad we only need potatoes”! Just outside the Concerto Avenida, Cyríaco enjoyed his recent celebrity, retelling his epic achievement over and over. He only had one complaint: they could take a better picture of him to place in the magazines. The magazine "O Malho" agreed to run a new article with a new picture under the headline: “Jiu-jitsu versus Capoeira: Cyríaco, the hero”. In addition, after many articles about the fight, the magazine found a way to restore the order turned upside down by Cyríaco’s victory. A 
cartoon published in the magazine called his triumph "the victory of a mulatto", blurring his African ethnicity. Transforming Cyríaco into a mestizo was almost certainly an attempt to make him palatable to the local elite. ${ }^{5}$

Round 2: "Rumble in the Jungle", Kodokan judo versus capoeira, the Brazilian Amazon 1915

In October, 1915, the newspaper Folha do Norte announced the vaudeville attractions that had recently arrived in Belém, capital of the State of Pará, in the Brazilian Amazon. Events were scheduled to take place in a local version of the Parisian Moulin Rouge, called Bar Paraense. The vast array of international performances advertised promised great excitement to entertain the cosmopolitan elite living on the Brazilian frontier. Among the Italian, French and American artists being promoted, a troupe of martial artists stood out. They were Japanese fighters performing jiu-jitsu and they defiantly offered 5,000 francs to anyone capable of beating them. ${ }^{6}$ The spectacle was promoted in great style by having the Japanese parade with their exotic jiu-jitsu outfits through the Haussmannian boulevards that had been built during the heyday of the rubber boom.

The season was a huge success. The local press was impressed with the Japanese fighters and coined the epithet "Nippon Hercules" to describe them. ${ }^{7}$ In keeping with the traditional vaudeville-styled martial art presentations of the time, they reserved part of their spectacle for amateurs to fight the professionals and compete for the previously stipulated prize money. Wrestlers, laborers, tough guys, and even vagrants were attracted by the possibility of pocketing 5,000 francs in a time of economic recession. ${ }^{8}$ Among the candidates, one in particular created a great deal of expectation. His nickname was Pé de Bola (ball foot), and he was a local street fighter and capoerista. He had become infamous over the years for his toughness in the poor periphery of Belém. He was also a henchman of Antonio Lemos, a fallen political boss ousted by an enraged mob in 1912. ${ }^{9}$ The excitement caused by the impending confrontation between Japanese jiu-jitsu and Afro-Brazilian capoeira led the public to experience a collective catharsis and temporarily forget Pé de Bola's bad reputation and his association with the former local tyrant.

Press and public patriotically closed ranks behind a man who once represented barbarism and old-fashioned politics. Satake Soishiro, who was picked to represent the troupe, was not an ordinary Japanese martial artist drifting through the West with dubious credentials. He and another martial artist who used the nom de guerre "Count Koma” were 
skilled martial artists and masters of the cutting-edge style of modern jiu-jitsu known as Kodokan judo. Newspaper headlines shouted: “Today: capoeira against jiu-jitsu! Everyone to Bar Paraense!" 10 Satake easily defeated Pé de Bola, causing profound disappointment among local patriots. The newspaper covering the event sarcastically observed that the tragic local hero never had a chance to use his famous rabo de arraia (stingray tail). Worse still, "he did not even try a simple rasteira (foot sweep), a basic technique used by any kid in the streets."

It is tempting to imagine that among those who poured in to watch the fight was the owner of a local circus, named Gastão Gracie. Gracie, the scion of an upper-class ScottishBrazilian family from Rio de Janeiro, was the son of a former slave owner, but he was also cosmopolitan, sophisticated and educated, and he had modern standards. He, like the Japanese fighters, had been attracted by the riches of the rubber boom in the Amazon. If he was at the fight, he would have been pleased to witness the Japanese fighter's triumph. He had been among those who actively participated in the violent overthrow of Pé de Bola's political patron.

One journalist covering the event, who had steadfastly supported capoeira prior to the fight, wrote a public apology. "He admitted that he, like most Brazilians of his rank, had naively fallen under the spell of street capoeira. But he concluded in relief: fortunately not all Brazilians believe in it.”11

\section{Turn-of-the Century Brazil: Modernization, the Navy and Japanese jiu-jitsu}

Brazilian elites began to discuss modernization as early as the mid-nineteenth century, but the implementation of measures aimed at bringing about modernization were accelerated with the dawn of the monarchy and the proclamation of the republic in 1889. A comprehensive range of policies were envisioned by the Brazillian elite to make the country viable as a modern nation, following the standards set in Europe, and, to a lesser extent, in North America. $^{12}$

Immigration to Brazil was encouraged in order to meet the growing demand for labor after the abolition of slavery. Simultaneously, immigration was also used as a strategy to reconfigure the ethnic fabric of Brazilian society. ${ }^{13}$ Japan, by the late nineteenth century, emerged as a potential source of migrants to help keep Brazil's export-commodity economy running. ${ }^{14}$ Unlike the previous failed attempt with Chinese immigration, Japan's image was associated with a paradox: it was both a source of labor and a paradigm of modernization. ${ }^{15}$ 
The new republican regime established formal diplomatic relations with Japan in 1895, demonstrating growing interest in Meiji modernization. ${ }^{16}$ Brazilian diplomats stationed in Japan emphasized Japanese superiority over the Chinese. According to Henrique Lisboa, the former possessed initiative, inventiveness and adaptability that enabled them to perform tasks rapidly, and with economy and efficiency. Such qualities made the Japanese epitomes of modernity in the eyes of the Brazilian elite. On the other hand, according to Lisboa, Chinese indolence and lack of efficiency confirmed their backwardness, making them unfit as immigrants to the modern Brazil. ${ }^{17}$

Cultural aspects of Japanese lifestyle did not escape the gaze of Brazilian diplomats. Manoel de Oliveira Lima, the Brazilian consular representative, produced a lengthy traveller's account. Observing a popular theatrical spectacle in Kyoto in 1903, he described "this style of local capoeira peculiar to Japan known as jiu-jitsu, in which one takes the opponent down by grabbing his legs.” ${ }^{18}$ Oliveira Lima was a Catholic intellectual and diplomat "who brought images of Japan to a broad elite audience.”19

Diplomats were not the only ones keeping an eye out for modern trends abroad. The Brazilan Navy, in particular, was in a privileged position to observe innovations once its warships were assigned to regular instructional seafaring as early as 1870, and to circumnavigational cruises after 1879 , which included visits to Japan. ${ }^{20}$ The military had been an active supporter and promoter of modernization since the War of the Triple Alliance (1864-1870) against Paraguay. ${ }^{21}$ They became staunch supporters of Auguste Comte's positivism and evolutionary thought. ${ }^{22}$

After their victory over the Russians in 1905, Japan unquestionably consolidated its status as modern nation for Brazilians. ${ }^{23}$ The military intelligentsia, in particular, was amazed by Japan's performance in the battlefield and enthusiastically embraced its formula of using martial arts as a tool to promote eugenic improvement. In 1905, Navy officers Captain Santos Porto and Lieutenant Adler de Aquino translated a jiu-jitsu manual written by the American author Harrie Irving Hancock, entitled “Japanese Physical Training; the System of Exercise, Diet, and General Mode of Living That Has Made the Mikado People the Healthiest, Strongest, and Happiest Men and Women in the World". ${ }^{24}$

The most interesting section of the book, however, is the introduction written by Captain Santos Porto, who presents the concerns he and the Brazilian elite had for the future of a vast nation being held up by the "fragile and broken” Brazilian race. He also praises efforts made by sports associations to develop a more physically fit population in such climatically unfavorable conditions, despite poor nutrition and a traditional lack of physical 
activity. ${ }^{25}$ According to Santos Porto, the weakness of Brazilian bodies contrasts starkly with the country's exuberant nature, and physical education would help to overcome years of neglect. He states, for example, that Afro-Brazilian capoeira's failure as a native school of physical education was largely due to the maladies of the past monarchical regime. ${ }^{26} \mathrm{He}$ claims that there was a time, at least in an imaginary past he envisions, that masters and slaves idyllically practiced capoeira side by side:

He remembered the times when capoeira flourished even among the sons of distinguished families, taught by domestic slaves. The later misuse of capoeira by vagrants and criminals led to the abandonment of an excellent school of physical education. ${ }^{27}$

This supposedly mild and patriarchal relationship was corrupted by a monarchy which made capoeira unable to fulfill modern republican needs. For this reason, Santos Porto proposes adopting Japanese jiu-jitsu to help prepare young Brazilians to perform the noble deed of ruling over the nation-continent. ${ }^{28}$ Santo Porto's reservations about capoeira reflect the project of modernization envisioned by republicans. Because Brazilian capoeira was quintessentially African, it was irreversibly linked to the embarrassing past of slavery. This definitely compromised its adoption at the time. ${ }^{29}$

Santos Porto and Radler de Aquino represented a progressive type of Navy officer, fiercely republican and nationalist. ${ }^{30}$ The former held a high-profile position within the republican establishment and was an active contributor to magazines, with articles that demonstrated a degree of cultural vanguardism. ${ }^{31}$ The intellectual approach displayed by the naval officers was in keeping with a small and embryonic intellectual movement that resisted complete acceptance of racist European theories. Instead they followed intellectuals such as Alberto Torres, who, as Thomas Skidmore has observed, avoided a "deterministic cul-de-sac" imported from Europe. Torres sought to explain Brazilian racial inferiority and Brazil's troubles by mixing ideas of environmental determinism derived from neo-Lamarckism with groundbreaking studies by the anthropologist Franz Boaz. ${ }^{32}$

The cultural discourse voiced by the navy officers through the booklet is crucial to understanding the prevalent zeitgeist during the introduction of Japanese jiu-jitsu in the first decades of the 1900s. Santos Porto and others vanguardist intellectuals enthusiastically promoted Japanese jiu-jitsu, while leaving room for the redemption of capoeira. This ambiguous attitude could also be found within the military establishment. Initiatives to adopt capoeira as a method of physical education were introduced almost simultaneously to Santos 
Porto’s support for jiu-jitsu. In 1907, for example, the manual Guia do Capoeira ou Gymnástica Brasileira (Guide to Capoeira or Brazilian Gymnastics) was published. ${ }^{33}$ The author, despite claiming to be a high ranking army officer, remained anonymous. His behavior starkly contrasted with that of Santos Porto and Radler de Aquino, who openly advocated the adoption of Japanese jiu-jitsu.

Articles published in the Rio de Janeiro press praising Cyríaco’s triumph over the Japanese provided a picture of how ideas of race had evolved at the time of this martial arts showdown. As demonstrated in the snapshot at the beginning of this chapter, Cyríaco's obvious blackness was subtly neglected. Furthermore, an article written by the intellectual Lima Campos in Kosmos magazine in 1904 is revealing: "Capoeira is invented by mestizos. It is not black, it is not mulatto, or cafuzo (Black and Indian), or mameluco (Portuguese and Indian). It is totally mixed.” ${ }^{\text {}}$ This attempt to praise racial miscegenation, voiced through Lima Campos's piece years prior to the fight, helps to shed light on the distortions of Cyríaco’s ethnicity. It also confirms a strategy to make capoeira acceptable in the mainstream, as observed by Maya Talmon-Chvaicer: "to become socially acceptable it had to be presented as a national activity, integrating the talents and abilities of the three major races in Brazil.,35 By avoiding adherence to European ideas, but also ignoring Afro-Brazilians, the Brazilian progressive intelligentsia resorted to what Carl Degler defined as the "mulatto escape hatch."36 The cultural vanguard, while swimming against the inexorable stream of Aryan ideals professed by the majority of intellectuals, did not seek to redeem blackness after all. They promoted mestizaje as the discourse of the Brazilian elite, in order to perpetuate racism and keep Afro-Brazilians marginalized.

\section{From Mayeda to “Count Koma": Kodokan judo and vaudeville jiu-jitsu}

Modernization in the early 1900s prompted the globalization of Japanese culture. Growing interest in Japanese jiu-jitsu, as demonstrated by the military in Brazil, was a widespread phenomenon. ${ }^{37}$ In addition to the military, police forces sought to learn new techniques for controlling the urban masses and for fighting the growing criminality that accompanied the social changes brought about by modernization. ${ }^{38}$ On the other hand, after centuries of isolation, the Japanese were driven by immigration and nationalistic expansion. ${ }^{39}$ As Sabine Frühstück and Wolfram Manzenreiter affirm: 
Kano (Jigoro) was highly successful precisely because he managed to arrange judo along the developmental axis of lifelong improvement and within the structural framework of a modern Western sport. In terms of integration, the new cultural space that Kano had opened found appropriate niches in Japan as well as in the Western world. ${ }^{40}$

Niches were created for martial artists leaving Japan in the early twentieth century. Mayeda Mitsuyo was a university student attracted by the expansion of the Kodokan judo school created by the young Japanese intellectual and jiu-jitsu practitioner named Kano Jigoro during the mid-Meiji era. ${ }^{41}$ He joined the Kodokan dojo in 1897 and became a graduate student after his promotion to first degree black belt (shodan) on January 8, 1899. ${ }^{42} \mathrm{He}$ trained under the instructor-chief, Yokoyama "Devil” Sakujiro, and rose rapidly to a fourth degree black belt (yondan) in the newly established belt ranking system created for modern jiu-jitsu. $^{43}$

During the Russo-Japanese War, Mayeda Mitsuyo and Tomita Tsunejiro, a veteran Kodokan judo master, traveled to America. ${ }^{44}$ After a presentation at the West Point Military Academy they parted ways, and soon afterwards Mayeda began to wrestle professionally. ${ }^{45}$ Mayeda set out on a globetrotting journey as a wrestler, which took him to Europe and Latin America. In the course of his professional career he adopted the nom de guerre "Count Koma."46

Mayeda's involvement with professional wrestling made his relationship with the Kodokan judo school problematic. This is clear because he and other professional Japanese fighters had their belt promotions slowed down enormously. ${ }^{47}$ According to Paul McMichael Nurse, in the early days of Kodokan, all practitioners were required "to place a seal of blood on an open register and declare five oaths." In two of them, it was stated "I shall not bring dishonor for the dojo" and "first as student, and later as instructor, I will always obey the dojo rules.”48 The case of Tokugoro Ito, a Kodokan black belt involved in professional wrestling with Mayeda, is revealing. In the aftermath of the former's defeat by the American wrestler Ad Santel in San Francisco in 1916, the Kodokan headquarters issued a response: "The Kodokan replied that it permits mixed bouts with boxers and wrestlers for research purposes, but prohibits such bouts when they are employed for personal monetary gain." ${ }^{49}$ In addition, Kano Jigoro, the founder of the Kodokan dojo declared:

No one is allowed to take part in public entertainment for personal gain. Teachers certainly receive remuneration for their services, but that is in no way degrading. The professional is held in high regard like the officers of a religious organization or a professor in the educational world. Judo itself is 
held by us all in a position at the high altar. To reconcile this point of view with the Western idea is difficult. ${ }^{50}$

In addition to these principles of Kodokan judo, in 1909 Kano Jigoro became deeply involved with the Olympic movement. For him and other modern educators of Meiji Japan, sport was synonymous with amateurism. ${ }^{51}$

In 1912, in Mexico, Mayeda was promoted by the Kodokan to a fifth degree black belt (godan) and it was his last belt promotion for seventeen years as well was the last time that he used the specific denomination of his jiu-jitsu school as "judo" during the 1910s. ${ }^{52}$

Public matches pitting Japanese jiu-jitsu against other martial arts disciplines, such as those of Brazil or of the United States, became the rage in Western countries. ${ }^{53}$ The Japanese method was trying to establish its version of modernity by combining maximum efficiency with minimum use of energy at a time when these were concepts important to industrialization. ${ }^{54}$ Whether out of necessity or not, Mayeda found a dynamic market for blood-sport prizefighting bouts and Vaudeville-like presentations, and he remained involved in these events for fourteen years.

After traveling through the United States and Europe, Mayeda set off to Latin America and performed in Cuba and Mexico between 1908 and 1912. ${ }^{55}$ In both countries he advertised his martial art in eclectic ways. In Mexico, for example, he performed at bullfight arenas in the countryside and in gala presentations for Porfirio Diaz at the Chapultepec Military Academy during the dawn of the Porfiriato. ${ }^{56}$ Mayeda, already using his stage name "Count Koma”, performed at the Colon Theatre in Mexico City, leading to what the English-language newspaper “The Mexican Herald” called "the wrestling boom."57

The image of Japan as an emerging power certainly helped to arouse the interest of Latin Americans in jiu-jitsu. ${ }^{58}$ As Heather Levy has pointed out, there was a close association linking sports with modernization and emerging nationalism. ${ }^{59}$ Together with a troupe of Japanese martial artists, Mayeda traveled through Central America to South America, arriving in Peru in 1913. There, he found a sizeable Japanese community which had been established in the late 1800s. As in Mexico and Cuba, a newspaper representing British and American interests and published in English, The West Coast Leader, provided an account of Count Koma's first match in Lima. He fought and defeated his compatriot Akyiama at Plaza de Acho, the oldest bullfighting arena outside Spain. The newspaper also disclosed that Count Koma was a graduate of the prestigious Waseda University, a "correspondent of several Japanese newspapers,” a skilled practitioner of football and baseball, and fluent in English. ${ }^{60}$ 
In 1914, Mayeda Mitsuyo and his troupe of martial artists arrived in Brazil at its southern border, after travelling to Argentina and Uruguay. ${ }^{61}$ This is understandable considering that the economic and cultural boom made platense cities like Buenos Aires and Montevideo mandatory ports of call for artists touring South America. After performing in Brazil's main capitals he reached the Brazilian Amazon in late $1915 .^{62}$

\section{Transnational encounters: The Gracies and Mayeda}

In 1915, the Japanese troupe arrived in Belém, the capital of Pará State and the largest urban center in the Brazilian Amazon. Cultural life in the metropolis still flourished at the dawn of the belle époque ${ }^{63}$. Theatres, opera houses and other public spaces in the region sprang up with the rubber boom to entertain the emerging local elite. Belém’s newspaper Folha do Norte announced the new attractions:

The Italian duo Sereia (The Mermaid), the French singer, Madam Germaine Derval and Dandy \& May, the American duo of singers and dancers performing eccentric performances. The troupe will perform jiu-jitsu, wresting, boxing and Japanese fencing matches and is directed by the undefeated world champion Count Koma. He will offer 5,000 francs for anyone able to defeat one of the troupe's members formed by Okura, champion of Chile, Shimizi, champion of Peru, Satake, champion of New York and Luku (Laku) a former military instructor in Peru. The troupe is currently in the state of Pará on its way to North America. Its performances were met with great success in other countries. The troupe will be dressing proper and decent attire, and its performance is rigorously family oriented. The troupe will parade through the streets in their traditional outfits. ${ }^{64}$

The Bar Paraense theater was a modern multifunctional space which accommodated stage performances and movies while functioning as a beer hall. Its ice and refrigeration allowed patrons to enjoy imported food and cold beverages, which were highly valued in the tropics. The beer house sold low-alcohol beer that was more suitable for the moderate behavior demanded by the life-style of the elite, while urban workers and rubber tappers in the forest tended to drink stronger alcoholic spirits. ${ }^{65}$ Turn-of-the-century modernization was an all-encompassing process, defined by one local aristocrat as a "purification of our customs."66 Theatres, for example, were the favorite rendezvous of the local elite for socializing and living their fantasy of civilization. The mention of "decent jiu-jitsu attire”, highlighted by the newspaper, indicates that spectacles staged at theatres in the Amazon in 1915 were still family-oriented, following the moral standards established at the height of the belle époque. $^{67}$ 
The rubber-based economy turned the Brazilian Amazon into an international entrepot connected to the great urban centers of Europe and the United States. Foreign currency circulated freely in the cities of Belem and Manaus. ${ }^{68}$ The prize of 5,000 francs offered by the Japanese was equivalent to five of the most expensive tickets for the spectacle (balconies). On the other hand, the French currency was experiencing a strong devaluation due to World War I. Therefore, offering a prize in francs may have been the Japanese troupe's strategy for minimizing any eventual loss of their own. With regard to the mandatory use of the jiu-jiu gis, apart the issue of morality, it was of great advantage to the Japanese to have lapels and sleeves with which they could apply their techniques. It is of particular note that all challengers attracted by the prize money were invariably defeated, leading the theatre's owner to raise the value of the prize. ${ }^{69}$

The capitals of the Brazilian Amazon during the rubber boom sought to follow cultural trends in vogue in the great international metropolises such as Paris. Patricia Tilburg describes the French music hall of the same period:

The belle époque music hall blended sport and the performing arts in highly physical spectacles that celebrated bodily fitness as an essential accompaniment of the life of the mind and of art. Max Viterbo parodied the pervasive integration of music hall and sport in a one-act play, Le sport au théatre en 1909 (Sport at the Theater in 1909). As the play opens, a theater director practices jujitsu, lifts weights, and discusses the need for sportrelated additions to an upcoming romantic play. ${ }^{70}$

Spectacles staged at this tropical "Moulin Rouge” with Japanese martial artists sought to reach cosmopolitan audiences looking for "spectacular experiments." ${ }^{71}$ The Japanese presentations, however, remained costly compared to the price of a movie ticket. ${ }^{72}$ If the cost of the most inexpensive ticket (standing room) to watch the Japanese fighters was apparently reasonable compared to the average blue collar income in Brazil, one should also take into consideration that local per capita income fell almost five times during the downturn in the rubber-based economy between 1910 and 1920. It certainly made entertainment off-limits to lower classes. $^{73}$

Concurrent to his stage performances, Mayeda Mitsuyo opened his first jiu-jitsu school at the Teatro Moderno in 1915:

Good news in the realm of sports.

We will have lessons in the favorite branch of Japanese sport: jiu-jitsu. Count Koma, currently performing on the stage of Bar Paraense, will stay with us to teach jiu-jitsu. Appropriate attire (gis) will be provided for 
children and adults. Count Koma also wants to teach jiu-jitsu in our private schools. We recommend for youngsters interested in physical fitness to enroll in jiu-jitsu lessons taught by the Japanese at Teatro Moderno. ${ }^{74}$

Among the children of the cosmopolitan elite searching for modern avenues of education and physical prowess, there was a teenager named Carlos Gracie. He was the eldest son of Gastão Gracie, the owner of the American Circus. In an interview given sixty-five years later, he remembered his membership of Count Koma’s dojo:

The Japanese arrived in Belem. Soon afterwards, they showcased a presentation at Teatro da Paz. People were amazed with their performance and I headed to Count Koma's dojo located at Rua Tamandare (Teatro Moderno). I was physically frail and had an inferiority complex, but I learnt the secrets of jiu-jitsu under the paternal supervision of the Japanese master. $^{75}$

Mayeda Mitsuyo returned to Belem in February of 1916, after a season in Manaus. Carlos Gracie, therefore, began to learn jiu-jitsu at the dojo which had been established at the Teatro Moderno sometime in $1916 .^{76}$

Along with the theatres and cinemas created to entertain the emerging bourgeois in the Amazon, circus closed their tents, staging blood-sports-type spectacles. These violent performances were appealing because cities of the region, such as Manaus and Belem, still retained much of the atmosphere of boom towns. ${ }^{77}$

Gastão became a partner in the American Circus and manager of the Italian-Argentine wrestler Alfredo Leconte in $1916 .{ }^{78}$ The paths of Mayeda and Gracie crossed because Leconte fought and defeated the overconfident Japanese ju-jitsu practitioners twice. First, in December of 1916, he defeated Uenish Sadakazu in Manaus, and few weeks later he defeated Shimizu Kusaku in Belem. ${ }^{79}$ On both occasions, Gracie cleverly manipulated the bouts by using confusing rules and suspicious refereeing. ${ }^{80}$ In Manaus and Belem, Leconte not only refused to wear gis but also had his body covered with grease, and whenever he was cornered he slipped out of the ring into the escape area. Furthermore, he won twice by using an identical strategy: he would have the Japanese fighter pinned down briefly, and without the referee waiting for the previously established thirty-second hold-down, he would be declared the winner. ${ }^{81}$

Unlike the family-oriented theatres, circuses like the one owned by Gracie were more flexible in relation to the fighters' dress code and rules of play. Ignoring moral concerns relating to the exposure of the half-naked wrestlers' bodies, Gracie cleverly prevented the 
Japanese from having lapels and canvases to apply their techniques to. The brawl that erupted after both fights suggests that a different kind of audience attended these violent performances. In Manaus and Belem, police suspended prizefight wrestling after the disturbances. $^{82}$

Gracie and Mayeda became acquainted in the aftermath of these encounters. The Scottish-Brazilian quasi-diplomat and the Japanese university-educated martial artist shared mutual business interests in the Brazilian frontier ravaged by economic crisis.

The Gracies were not originally from the ranks of the local middle class that emerged in Brazil during the first decades of the $1900 \mathrm{~s} .{ }^{83}$ Instead, they fell into the social category of the déclassé descendants of traditional families who were traumatically thrown into a middle class social limbo and struggled in a more competitive and complex social environment during the modernization period. ${ }^{84}$ For them, the capoeirista Pé-de-Bola, who fought the Japanese ju-jitsu practitioners, was a human metaphor for backwardness, as well as being the henchmen of a provincial political boss. Gaston Gracie's generation was still haunted by the presence of scores of dark-skinned Brazilians liberated from slavery in 1888 and forsaken by modernization in the early 1900s. ${ }^{85}$ Therefore, he had strong reasons to befriend the cosmopolitan "Count Koma” and encourage his eldest son to learn modern jiujitsu with the Japanese fighter.

The young Gracie's apprenticeship under Mayeda, and his local senior student Jacyntho Ferro, lasted no more than three years. ${ }^{86}$ Carlos's exposure to Mayeda's teachings was influenced by a circumstantial combination of factors that determined the nature of his apprenticeship. It is important to note Mayeda's lack of interest in training students to give continuity to the Kodokan judo school. He ignored, for example, the belt ranking system conceived by Kano Jigoro, which constituted one of the pedagogical foundations of the Kodokan judo school. ${ }^{87}$ He taught judo techniques to his students with a method that gave little emphasis to philosophical concepts or a pedagogical framework. Therefore, students like Carlos Gracie learned an eclectic program that mixed judo with wrestling. For Carlos, particularly, this would have made more sense, since the Gracies were in the business of professional wrestling. Moreover, Mayeda and Jacyntho Ferro were deeply involved in prizefighting at this time.

Under these circumstances, in employing the generic label "jiu-jitsu", instead of the specific name "judo", in accordance with his school, Mayeda was only being consistent with his momentary status as a prizefighter. Lastly, the absence of graduate students with the rank 
of black belt who had trained under Mayeda in the Amazon is emblematic; it only confirms the nature of Count Koma's teachings. ${ }^{88}$

The Gracies’ trajectory in the Amazon ended between 1919 and $1920 .{ }^{89}$ Carlos Gracie stopped training with Mayeda when his family moved to Rio de Janeiro, but Mayeda's career in Brazilian martial arts continued for decades. The Gracies returned to their elitist cradle in Rio de Janeiro after the death of Peter McNichols Gracie; for them, it symbolized the end of their long nineteenth century. For Carlos, a teenager trained in a pidgin, modern combat sport, this pidgin became a cultural asset during hard times. However, he also carried another asset equally essential to his social redemption: the Gracies’ patrician ethos.

\section{Count Koma to Mayeda “Otavio” Mitsuyo: from vaudeville jiu-jitsu to judo}

Mayeda Mitsuyo settled permanently in Belém. In July 1920, he performed his last public fight in Brazil against the Italian wrestler Victorio Segato at the Palace Theatre. ${ }^{90}$ The evening's eclectic entertainment program included the screening of the motion picture "The Song of Songs”, staring American actress Elsie Ferguson, followed by a four-round match. Before a full house, including high-profile members of the local elite and foreign expatriates, he finished off the Italian with a "spectacular" arm-bar. The newspaper covering the event acclaimed jiu-jitsu's superiority, and that Mayeda's “feline perspicacity” had prevailed. ${ }^{91}$ In 1921, he traveled overseas to compete in his last tournament. He first went to New York and then to Cuba, where he participated in a wrestling contest. ${ }^{92}$ Mayeda returned in triumph to Belém in July, 1922. His pupil Jacyntho Ferro welcomed his master in a small boat off the harbor. $^{93}$ From 1923 onward, he became involved in the project of settling Japanese immigrants in the Amazon. This shift from artistic persona to local liaison with the Japanese empire epitomizes the change in his status and respectability.

In 1919, the entire traditional system of Japanese martial arts, Bujutsu, was officially changed to the modern denomination Budo. Thereafter, all martial arts increasingly used the suffix $d o$, replacing and permanently dispensing with the medieval-rooted suffix jutsu. Moreover, in the 1920s and 1930s, Budo expanded greatly, supported by Japanese nationalism and militarism. ${ }^{94}$ Mayeda would ride the winds of change, and events in Japan probably influenced his return to the martial art orthodoxy represented by the school of Kodokan judo. 
Mayeda became actively involved in efforts to implement Japanese projects in the Amazon, particularly after the Kanto Earthquake of $1923 .{ }^{95}$ J. Charles Schencking has discussed the tremendous post-traumatic impact of this event on Japanese minds:

Commentators from diverse backgrounds believed that if this feeling of reflection was successfully managed or manipulated, it could be used to encourage all Japanese subjects to change their lifestyles. Privy Councilor Ichiki Kitokurō epitomized this mindset by suggesting that the earthquake "provided a rare opportunity to reflect upon our attitudes" that would, if used effectively, allow for the "reinvigoration of the popular mind" and thus improvement in every aspect of life. Alternatively, some suggested the disaster might enable the state to implement increasingly interventionist policies aimed at eliminating vices and luxuries that tempted people and weakened the nation. ${ }^{96}$

Coincidently or not, the timing of events in Japan established a watershed in Mayeda's role as an agent of imperial designs. His deep involvement made him an object of concern and he was investigated by the U.S. Department of State. ${ }^{97}$ The restoration or redemption of his Japaneseness is unquestionably proved by his promotion to a sixth degree black belt (rokudan) in June, 1929. ${ }^{98}$ Crowning Mayeda's allegiance to his martial arts alma mater, and at the height of Japan's nationalism, in 1935 he published a manual in Portuguese entitled “Jiudo: Uma Arte de Cultura Physica Japoneza” (Jiudo: An Art of Japanese Physical Education). The booklet essentially reproduced Kano Jigoro's lectures, particularly one he delivered in Singapore in $1933 .{ }^{99}$ In his final remarks, Count Koma explained the use of martial arts denominations:

Kodokan judo achieved the most widespread success ever experienced by a school of jiu-jitsu. It must be remembered that the word judo had been used by the Jikishin-ryu (school) long before Kodokan. This led some traditional jiu-jitsu schools to give up their original denominations and embrace the modern term which in turn caused misinterpretations of determining differences between judo and jiu-jitsu. Thus, I would say that our martial art is the Kodokan judo and I have employed the generic term jiu-jitsu in this book to describe other schools. ${ }^{100}$

Mayeda's remarks subtlety disclose the random use of terms during his past professional career by resorting to a semantic subterfuge. In fact, he used the generic term “jiu-jitsu” during his “dishonorable” period of vaudeville activities.

The pictures displayed in the book are rather symbolic. Kano Jigoro is shown wearing the traditional Japanese kimono and below them reads the text: "Senator Professor Dr. Jigoro Kano. Honorary professor of the High Normal College, president of Kodokan (founder and 
inventor of jiu-do); President of the Japanese Amateur Athletic Association.” Unquestionably, at this point, Kano reached a near mystical status. ${ }^{101}$ Three other photographs picture Mayeda with his Navy students on board a warship, symbolizing his status in his new country. ${ }^{102}$ Naval officers had begun using jiu-jitsu a generation earlier and they remained supporters of Japanese modernization.

Mayeda Mitsuyo became a Brazilian citizen in the heyday of a different nationalism: that of Brazilian. In 1937, he added the local given name "Otavio" to his name. This reflected the wave of nationalism that encouraged foreigners, especially those considered inassimilable, like the Japanese, to adopt a local identity. He died a week prior to the Japanese raid on Pearl Harbor. His last belt promotion to seventh degree black belt (shichidan) was issued by the Kodokan headquarters but arrived after his passing. ${ }^{103}$ The Gracies, however, had long since moved forward, taking the generic label "jiu-jitsu" with them to the epicenter of Brazilian nationalism.

\section{MODERNIZAÇÃO, NACIONALISMO E A ELITE: a origem do jiu-jitsu brasileiro, 1905-1920}

\section{Resumo}

Este artigo é parte da minha tese de doutorado intitulada The Gracie Clan and the Making of Brazilian jiu-jitsu: National Identity, Culture and Performance, 1905-1993 na qual eu trabalho com a introdução, criolização e globalização de uma arte marcial de origem japonesa conhecida como jiu-jitsu. A arte marcial híbrida desenvolvida no Brasil a partir da matriz japonesa pela família Gracie é produto do conflito entre tradição e modernidade que ao longo do século XX se transformou em um complexo ritual de hipermasculinidade baseado em violência " made in Brazil ». Meu artigo é dividido em duas partes nas quais eu analiso a introdução do jiujitsu no Brasil no início do século XX como parte do processo de modernização em âmbito global. Na primeira parte, a narrativa se desenrola no Rio de Janeiro no início do século XX e examina a adoção do jiu-jitsu como escola de educação física e patrocinada por militares. Esta seção está simbolizada na vinheta « $1^{\circ}$ Round ». Na segunda parte, a narrativa se desloca para a Amazônia durante a I Guerra Mundial aonde uma versão modernizada do jiu-jitsu japonês é introduzido de forma definitiva como resultado do encontro de caráter transnacional entre uma trupe de artistas marciais japoneses e uma família de brasileiros de origem escocesa. A segunda parte do artigo esta representada na vinheta « $2^{\circ}$ Round ».

Palavras-chave: Modernização. Identidade. Nacionalismo. Raça. Performance.

Recebido em: 21/05/2011 Aprovado em: 02/08/2011

\footnotetext{
${ }^{1}$ Cyríaco was born in 1871 in the town of Campos dos Goytacazes, situated in the northern region of Rio de Janeiro province. In the same year, the "Law of the Free Womb" was promulgated, freeing the offspring of enslaved Afro-Brazilians.

${ }^{2}$ The practice of capoeira was criminalized by 1890’s republican penal code. See Thomas H. Holloway, "'A Healthy Terror": Police Repression of Capoeiras in Nineteenth-Century Rio De Janeiro," The Hispanic American
} 
Historical Review 69, no. 4 (1989): 671. Also see Maya Talmon Chvaicer, "The Criminalization of Capoeira in Nineteenth-Century Brazil," The Hispanic American Historical Review 82, no. 3 (2002): 535.

3 "Ginga" is believed to be a word of Bantu origin and it is one of the basic movements of capoeira. "It is one of the features that sets capoeira apart from all other martial arts. Roughly translated it means "swing” in English. What makes the ginga special is that it puts capoeiristas in constant motion, making them a very frustrating target for an opponent.” Nestor Capoeira, The Little Capoeira Book, Rev. ed. (Berkeley, Calif.[s.n.]: North Atlantic Books, 2003), 62.

4 “O Malho”, Rio de Janeiro, 1909 (48), 10-11.

${ }^{5}$ Cyríaco died only three years after his triumph over the Japanese fighter. O Estado de Sao Paulo, Sao Paulo, 05/19/1912.

${ }^{6}$ Folha do Norte, Belém, 10/28/1915.

${ }^{7}$ Folha do Norte, Belém, 10/28/1915.

${ }^{8}$ The rubber-based economy transformed the Brazilian Amazon into an international entrepot connected to the great urban centers of Europe and the United States. Therefore, foreign currency circulated freely in cities like Belem and Manaus. However, one can speculate that since the French currency was experiencing a strong devaluation due to World War I, setting a prize in francs could have been Count Koma's strategy for minimizing any eventual loss. The prize stipulated was equivalent to five of the most expensive tickets to the spectacle.

${ }^{9}$ Luiz Augusto Pinheiro Leal, "Capoeira, Boi-Bumbá E Política No Pará Republicano (1889-1906)," Afro-Ásia 32 (2005). Luiz Augusto Pinheiro Leal, A Politica Da Capoeiragem: A Historia Social Da Capoeira E Do BoiBumba No Para Republicano (1888-1906) (Salvador, BA: EDUFBA, 2008), 182-84.

${ }^{10}$ Folha do Norte, Belém 11/07/1915.

${ }^{11}$ Folha do Norte, Belém 11/10/1915.

12 Thomas Skidmore considers the 1870s the point in time when policies seeking to whiten the Brazilian population emerged. Thomas E. Skidmore, "Racial Ideas and Social Policy in Brazil, 1870-1940," in The Idea of Race in Latin America, 1870-1940, ed. Aline Helg, et al. (Austin: University of Texas Press, 1990), 7.

${ }^{13}$ Jeff Lesser, Negotiating National Identity: Immigrants, Minorities, and the Struggle for Ethnicity in Brazil (Durham, N.C.: Duke University Press, 1999), 4.

${ }^{14}$ Steven Topik and Mario Samper, "The Latin American Coffee Commodity Chain: Brazil and Costa Rica", in From Silver to Cocaine: Latin American Commodity Chains and the Building of the World Economy, 15002000, ed. Steven Topik, Carlos Marichal, and Zephyr Frank (Durham and London: Duke University Press, 2006), 122.

${ }^{15}$ Lesser, Negotiating National Identity: Immigrants, Minorities, and the Struggle for Ethnicity in Brazil, 38. Skidmore, "Racial Ideas and Social Policy in Brazil, 1870-1940," 12.

16 "Tratado de Amizade, Comercio e Navegacao" (Treaty of Friendship, Commerce and Navigation) signed in 1895 in Paris. Meiji Period (1868-1912).

17 "Respondendo a Industria", 1897. Arquivo Historico do Itamaraty.

${ }^{18}$ Oliveira Lima, No Japão: Impressões Da Terra E Da Gente, 3a. ed. (Rio de Janeiro, RJ: Topbooks : NEC do Brasil, 1997), 203. There are accounts about a certain Takezawa Manji, a Japanese martial artist hired to instruct the imperial guard of Brazil's last emperor Pedro II. Os imigrantes japoneses precursores: um olhar historico sobre o periodo pre-Kasatu Maru. Museu Historico da Imigracao Japonesa no Brasil. http://www.discovernikkei.org/en/, "Os Imigrantes Japoneses Precursores - Um Olhar Histórico Sobre O Período Pré-Kasato-Maru," in Crie historia ed. Nikkey Álbum (2007).

${ }^{19}$ Lesser, Negotiating National Identity: Immigrants, Minorities, and the Struggle for Ethnicity in Brazil, 154. Manoel de Oliveira Sobrinho (1867-1928) was a consular representative (Encarregado de Negócios) in Japan from 1901 to 1902.

${ }^{20}$ Historia Naval Brasileira, vol. 4 (Rio de Janeiro: Servico de Documentacao da Marinha, 2001), 109-12. Beattie, The Tribute of Blood: Army, Honor, Race, and Nation in Brazil, 1864-1945, 270.

${ }^{21}$ The "War of the Triple Alliance" (1864-1870) was a major military conflict in South America pitting Brazil, Argentina and Uruguay against Paraguay.

${ }^{22}$ Peter M. Beattie, The Human Tradition in Modern Brazil (Wilmington, DE: Scholarly Resources, 2004$), 113$.

23 “Russo-Japanese War" (1904-1905). As Jeffrey Lesser has put it: “Japan was a modernizing nation that had retained its exotic soul in an increasingly harmless way - could Brazil do the same?” Lesser, Negotiating National Identity: Immigrants, Minorities, and the Struggle for Ethnicity in Brazil, 149-50.

${ }^{24}$ J. A. Santos e Aquino Porto, F. Radler, Educacao Physica Japoneza (Rio de Janeiro: Companhia Typografica do Brazil, 1905). This book, translated by Navy officers, was essentially a canonic work on turn-of-the-century Japanese jiu-jitsu, published in its Brazilian version without any additional changes.

${ }^{25}$ Peter Beattie points out that the creation of Swiss-style gun clubs was encouraged by the Minister of War, Marshal Hermes da Fonseca, as a way of increasing public interest in military service. Beattie, The Tribute of Blood: Army, Honor, Race, and Nation in Brazil, 1864-1945, 209. 


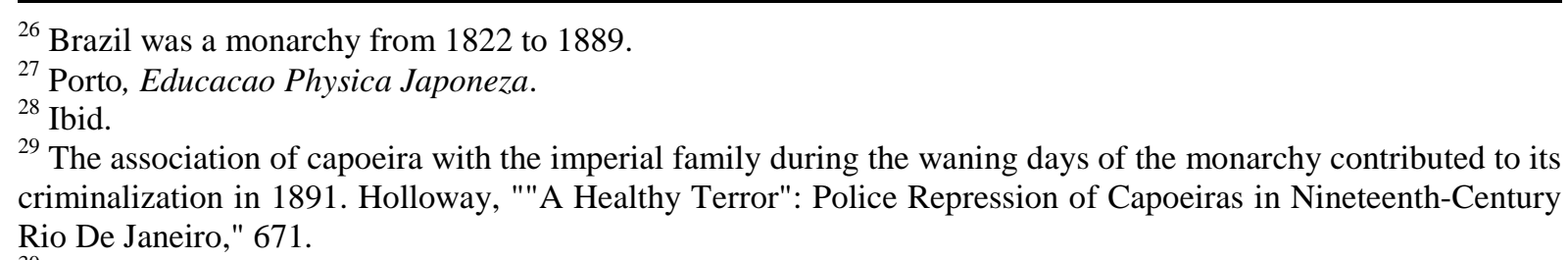

30 Frank D. McCann, "Origins of The "New Professionalism" Of the Brazilian Military," Journal of Interamerican Studies and World Affairs 21, no. 4 (1979): 510. Both naval officers fought to defend the republic against attempts to return the previous regime. Santos Porto was promoted "for distinguished services in defense of the republic.” Atanagildo Barata Ribeiro, Sonho No Carcere. Dramas Da Revolucao De 1893 No Brazil. Poema (Rio de Janeiro: Casa Mont'alverne, 1895), xxxv, xxxix.

${ }^{31}$ Santos Porto was chief of the Casa Militar. This high-profile post was occupied by a figure from the military who acted as a liaison between the two service chiefs (Army and Navy) and the president. Kosmos, Revista Artistica, Scientifica e Literaria, Anno 3, 1, Janeiro 1906.

32 Don Mitchell, Cultural Geography: A Critical Introduction (Oxford; Malden, Mass.: Blackwell Publishers, 2000), 18-20. Torres was one of the first to criticize biological determinism. Beattie, The Tribute of Blood: Army, Honor, Race, and Nation in Brazil, 1864-1945, 234. Lesser, Negotiating National Identity: Immigrants, Minorities, and the Struggle for Ethnicity in Brazil, 3-4. Jerry Davila, Diploma of Whiteness: Race and Social Policy in Brazil, 1917-1945 (Durham ; London: Duke University Press, 2003), 28.

${ }^{33}$ Guia Do Capoeira Ou Gymnástica Brasileira, (Rio de Janeiro: Livraria Nacional, 1907).

${ }^{34}$ Lima Campos, "A Capoeira," Kosmos, Revista Artistica, Scientifica e Literaria 1906. Jack D. Forbes and Jack D. Forbes, Africans and Native Americans: The Language of Race and the Evolution of Red-Black Peoples, 2nd ed. (Urbana: University of Illinois Press, 1993).

${ }^{35}$ Maya Talmon-Chvaicer, The Hidden History of Capoeira: A Collision of Cultures in the Brazilian Battle Dance, 1st ed. (Austin, TX: University of Texas Press, 2007), 112.

${ }^{36}$ Carl N. Degler, Neither Black nor White: Slavery and Race Relations in Brazil and the United States (Madison, Wis.: University of Wisconsin Press, 1986).

${ }^{37}$ Japanese jiu-jitsu was employed by armies and law enforcement agencies everywhere. Elites in the Western world showed growing interest in the martial art. Joseph R. Svinth, "Professor Yamashita Goes to Washington" in Martial Arts in the Modern World, ed. James A. and Svinth Joseph R. Green, eds. (Westport, Conn.: Praeger, 2003), 47 et passim. Michel Brousse, Le Judo: Son Histoire, Ses Succès (Genève: Liber, 1996), 56-57.

${ }^{38}$ Brazilian naval officers also supported the adoption of jiu-jitsu as a means of social control. In 1904, a riot broke out against mandatory vaccination. The barricades built by rioters were called "Port Arthur". Like the original one in Russia, which fell to a Japanese attack, Rios's counterpart fell to the forces of modernization. Jeffrey D. Needell, "The Revolta Contra Vacina of 1904: The Revolt Against "Modernization" In Belle-Epoque Rio De Janeiro," The Hispanic American Historical Review 67, no. 2 (1987).

${ }^{39}$ James A. Green and Joseph R. Svinth, "The Circle and the Octagon: Maeda's Judo and Gracie's Jiu-Jitsu," in Martial Arts in the Modern World, ed. James A. Green and Joseph R. Svinth (Westport, Conn.: Praeger, 2003), 63. "Japanese like Westerners must go abroad, work hard, in many areas of the world as possible under Japanese influence.” Akira Iriye, "Japan as Competitor, 1895-1917," in Mutual Images: Essays in American-Japanese Relations, ed. Priscilla Iriye Clapp, Akira Joint Committee on Japanese Studies, (Cambridge: Harvard University Press, 1975).

40 Sabine Frühstück and Wolfram Manzenreiter, "Neverland Lost: Judo Cultures in Austria, Japan and Everywhere," in Globalizing Japan: Ethnography of the Japanese Presence in Asia, Europe, and America, ed. Harumi Befu and Sylvie Guichard-Anguis (eds.) (London: Routledge, 2001).

${ }^{41}$ Kano Jigoro was born on October 28, 1860, in Mikage, in the Province of Hyogo. Kano graduated from the Department of Political Science and Finance at Tokyo Imperial University in July 1881. Inoue Shun, "The Invention of the Martial Arts," in Mirror of Modernity: Invented Traditions of Modern Japan, ed. Stephen Vlastos (Berkeley: University of California Press, 1998), 164.

${ }^{42}$ Mayeda Mitsuyo was born on November 18, 1878 in the Prefecture of Aomori in the northernmost point of Japan's main island of Honshu. In 1896, he moved to Tokyo to attend a preparatory school that later became Waseda University. Kodokan Archives, Tokyo, Japan.

${ }^{43}$ Yoshinobu Hamaguchi, "Innovation in Martial Arts," in Japan, Sport and Society: Tradition and Change in a Globalizing World ed. Joseph Maguire and Masayoshi Nakayama (London and New York: Routledge, 2006), 14. Shun, "The Invention of the Martial Arts," 167. Shun, "The Invention of the Martial Arts." He was promoted successively to the second degree black belt (nidan) on October 3, 1899, third degree black belt (sandan) on January 13, 1901, and fourth degree black belt (yodan) on October 23, 1904. Kodokan Archives.

${ }^{44}$ Tomita and Mayeda arrived in New York City on 12/08/1904 and went to West Point in January, 1905. Their presentation was part of a lecture given by the Imperial Japanese Legation on the Russo-Japanese War. Mayeda 
fought his first professional match in 1906 in Catskills (NY) and defeated the American wrestler John Piening, “The Butcher Boy”. Green and Svinth, "The Circle and the Octagon: Maeda's Judo and Gracie's Jiu-Jitsu," 6465. The New York Times, NY, 02/21/1905, p. 5.

${ }^{45}$ The New York Times, NY, 04/06/1905, p. 11.

${ }^{46}$ Michael Watt, "The Lengendary Story Of "Conde Koma" Mitsuyo Maeda," Judo Journal 20, no. 1 (JanFeb1997): 3-4.

${ }^{47}$ He was promoted through four degrees of the black belt (dan) from 1899 to 1904. It took eight years to get his fifth degree black belt (godan) and seventeen to receive his sixth degree black belt (rokudan). Kodokan Archives.

${ }^{48}$ Paul McMichael Nurse, "The Beginnings of Kodokan Judo,1882-1938," FightingArts.com.

${ }^{49}$ Joseph R. Svinth, "On the Defeat of Tokugoro Ito in North America," The Journal of Alternative Perspectives on the Martial Arts and Sciences, no. JAN (2006).

${ }^{50}$ Gunji Koizumi, "Jigoro Kano in a 1936 Conversation with Gunji Koizumi" JudoInfo.com. Joseph R. Svinth and Thomas A. Green, "The Circle and the Octagon: Maeda's Judo and Gracie's Jiu-Jitsu" in Martial Arts in the Modern World ed. Joseph R.Svinth and Thomas A. Green (Westport (CT): Praeger Publishers, 2003), 65.

${ }^{51}$ Yuko Kusaka, "The Emergence and Development of Japanese School Sport" in Japan, Sport and Society, ed. Joseph Maguire and Masayoshi Nakayama (London and New York: Routledge, 2006), 32.

52 The Mexican Herald, Mexico City, 08/27/1909, p. 5.

${ }^{53}$ Brousse, Le Judo: Son Histoire, Ses Succès, 33-35.

54 “Le jujutsu valorize l'employ de la force juste." Ibid., 36.

55 Japan Times, Tokyo, 11/01/1912.

${ }^{56}$ The Mexican Herald, Mexico City, 08/07/1909.

${ }^{57}$ In Mexico, Mayeda fought Americans, Europeans and other Japanese fighters. Hjalmar Lundin, On the Matand Off; Memoirs of a Wrestler (New York, N.Y.: Albert Bonnier publishing house, 1937), 90-91. Michael Watt, "The Lengendary Story Of "Conde Koma" Mitsuyo Maeda," Judo Journal 20, no. 5 (Sep-Nov 1997): 3-4.

${ }^{58}$ Daniel M. Masterson and Sayaka Funada-Classen, The Japanese in Latin America (Urbana: University of Illinois Press, 2004), 13-16.

${ }^{59}$ Heather Levi, The World of Lucha Libre: Secrets, Revelations, and Mexican National Identity (Durham: Duke University Press, 2008), 12.

${ }^{60}$ The West Coast Leader, Lima, 09/11/1913, p. 6.

${ }^{61}$ Rildo Heros de Medeiros's interview with Gotta Tsutsumi (Associação Paramazônica Nipako, Belém, Pará).

${ }^{62}$ O Estado de São Paulo, São Paulo, 09/27/1914, p. 4 and 10/08/1914, p. 2.

63 The economic crisis hit the local economy hard between 1910 and World War I. Weinstein, The Amazon Rubber Boom, 1850-1920, 258.

${ }^{64}$ Folha do Norte, Belém, 10/25/1915. The newspaper Folha do Norte actively promoted cultural life in Belém. It began circulation in 1896 and was opposed to Antonio Lemos, a local political boss deposed during the political crisis in 1912, in which Gastão Gracie participated. From then on, Folha do Norte supported the local cultural vanguard.

${ }^{65}$ Theatre Bar Paraense was inspired by the French Moulin Rouge. Vincente Salles, 210, vol 1.

${ }^{66}$ José Coelho da Gama Abreu, Baron of Marajó (1832-1906).

${ }^{67}$ Moralization of the Bar Paraense took place under the direction of Neapolitan maestro Raffaelo Segré, in 1908. Vicente Salles, Epocas Do Teatro No Grão-Pará, Ou, Apresentação Do Teatro De Época (Belém: Editora Universitária UFPA, 1994), 179.

${ }^{68}$ Maria de Nazaré Sarges, Belém: Riquezas Produzindo a Belle-Époque, 1870-1912 ([Belém, Brazil]: Editora Paka-Tatu, 2000), 85.

${ }^{69}$ Folha do Norte, Belém, 11/01/1915.

${ }^{70}$ Patricia A. Tilburg, Colette's Republic: Work, Gender, and Popular Culture in France, 1870-1914, 1st ed. (New York: Berghahn Books, 2009), 141.

${ }^{71}$ Ana M. Lopez, "'Train of Shadows": Early Cinema and Modernity in Latin America," in Multiculturalism, Postcoloniality, and Transnational Media, ed. Ella Shohat and Robert Stam (New Brunswick, N.J.: Rutgers University Press, 2003), 3.

${ }^{72}$ Folha do Norte, Belém, 10/28/1915. Prices ranged from $1 \$ 000$ to $10 \$ 000$. A factory worker in Rio de Janeiro received $110 \$ 000$ per month. Hildete Pereira de Melo, João Lizardo de Araújo, and Teresa Cristina de Novaes Marques, "Raça E Nacionalidade No Mercado De Trabalho Carioca Na Primeira República: O Caso Da Cervejaria Brahma," $57 \quad$ (2003), http://www.scielo.br/scielo.php?script=sci_arttext\&pid=S0034$71402003000300003 \& n r m=$ iso

${ }^{73}$ Roberto Santos, Historia Economica Da Amazonia (1800-1920) (Sao Paulo: T.A. Queiroz, 1980), 12-13-1415, José Márcio Rego; Rosa Maria Marques, ed., Economia Brasileira (Sao Paulo: Saraiva 2003).

${ }^{74}$ Folha do Norte, Belém, 01/18/1916. 


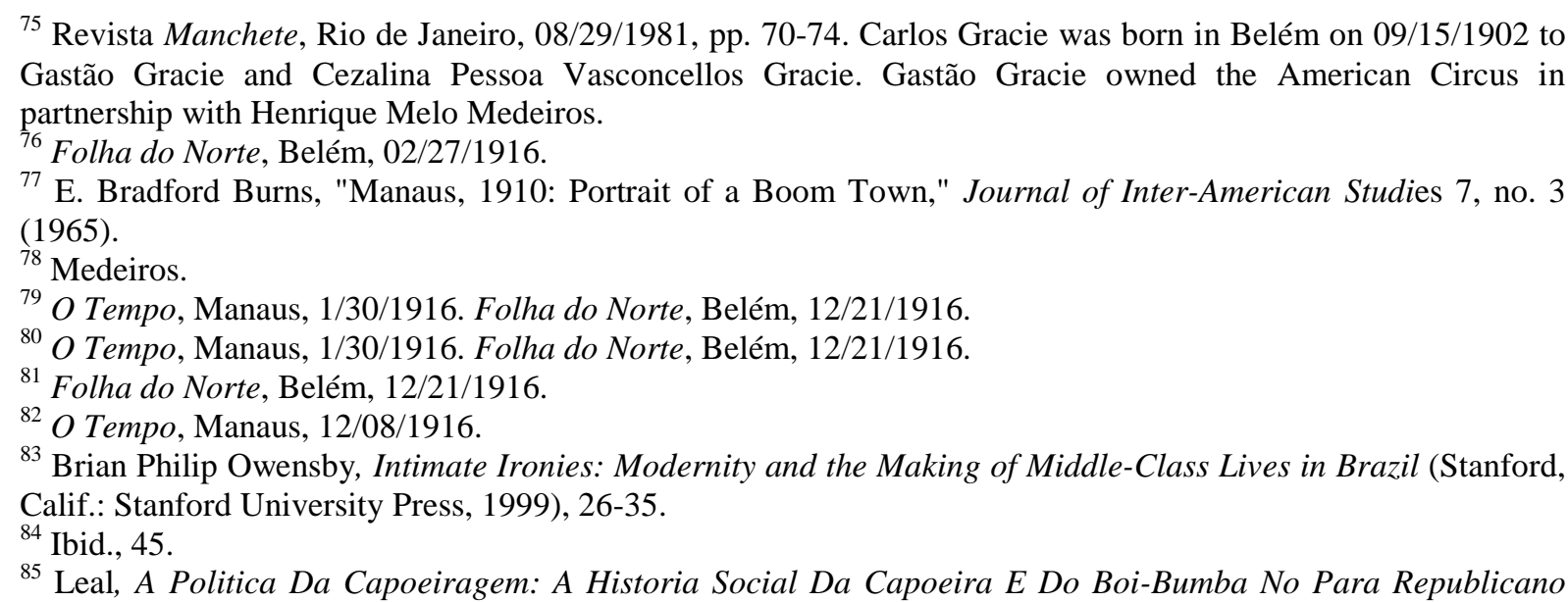
(1888-1906). Celia Maria Marinho de Azevedo, Onda Negra, Medo Branco: O Negro No Imaginario Das Elites-Seculo XIX (Rio de Janeiro, RJ: Paz e Terra, 1987), 219.

${ }^{86}$ Jacyntho Ferro was a local wrestler who joined Mayeda's dojo. He became Mayeda's chief instructor in Belém.

${ }^{87}$ Inoue Shun, "Invented Tradition in the Martial Arts," in The Culture of Japan as Seen through Its Leisure, ed. Sepp Linhart and Sabine Frühstück (Albany: State University of New York Press, 1998), 85-86.

${ }^{88}$ In 1928, Mayeda Mitsuyo confided to Hajime Otake that he had never awarded a black belt to any student in Brazil. Hajime Otake and Yamada Yoshio came from Japan together and settled in the Amazon in 1928. The latter was Mayeda's colleague from Kodokan, and the three Japanese developed a long friendship in their new home. In another interview given by Hajime Otake, at the age of 96 in Belém, he confirmed Mayeda's declarations. Otake Hajime Interview to Rildo Eros de Medeiros and Gotta Tsutsumi (head of Associação Paramazônica Nipako) in June 2006.

${ }^{89}$ In an interview, Carlos Gracie declared that his family left Belem when he was 17 years old. Revista Manchete, Rio de Janeiro, 08/29/1981, p. 70. Pedro (Peter) McNichols Gracie, Carlos's grandfather, died on 02/13/1921. Colegio Brasileiro de Genealogia, Arquivo Paulo Carneiro da Cunha, Rio de Janeiro, titulo 11: Gracie.

${ }^{90}$ Mayeda Mitsuyo was 41 years old.

91 The prices for "Count Koma's" last fight had increased considerably since his first presentation in 1915. Folha do Norte, Belém, 07/08/1920, p.4 and 07/09/1920, p.4.

${ }^{92}$ Sources cited in a Wikipedia article confirm Mayeda's participation in contests in Cuba. Ancestry.com. New York Passenger Lists, 1820-1957 (database online). Year: 1921; Microfilm serial: T715; Microfilm roll: T715_3023; Line: 2. Diario De La Marina, Havana, various dates, September-December 1921. Available at http://en.wikipedia.org/wiki/Mitsuyo_Maeda.

${ }^{93}$ Mayeda reported to a local newspaper that he had won an international jiu-jitsu prizefight in Cuba. He fought a fourteen-round bout against another Kodokan judo black belt named Tokugoro Ito. He forced Ito to submit with an arm bar and pocketed a US\$ 8,000 prize. In addition, he and his long-time companions parted ways. Okura and Satake remained in Mexico, teaching jiu-jitsu to the local police. Folha do Norte, Belém, 07/08/1922, p. 4. Mayeda returned to Brazil in the ship João Alfredo.

${ }_{94}$ Shun, "Invented Tradition in the Martial Arts."

${ }^{95}$ Folha do Norte, Belém, 05/03/1926, 05/14, 05/16, 05/24, 05/25, 05/29, 05/31, 06/14, 06/05 and 06/07. The New York Times described the Japanese project in the Amazon: "Tomé-Açu distant 197 kilometers of the capital Belém and became the pioneer camp for the Japanese immigration in the Amazon Valley.” The New York Times, NY, 01/05/1930, p. E7.

96 J. Charles Schencking, "The Great Kanto Earthquake and the Culture of Catastrophe and Reconstruction in 1920s Japan," Journal of Japanese Studies 34, no. 2 (2008): 304.

${ }^{97}$ Mayeda was also a shareholder of Companhia Niponica de Plantacões do Brasil S/A (Japanese Plantation Company of Brazil) branch of the Nankatu Co. Memorandum of Gerald A. Drew, US Vice Consul in Brazil, to Dr. Munroe, 27 June 832.52 J27/68S, US National Archives and Records Administration.

${ }^{98}$ The sixth degree signals the black belt holder's entry into an honorable upper division.

99 Jiudo, in Art of Japanese Physical Culture, (Singapore: Nanyo Printing Office, 1933).

100 Jiudo: Uma Arte De Cultura Physica Japonesa, (Belem: Livraria Escolar, 1935).

${ }^{101}$ In 1921, Kano Jigoro was granted membership of the House of Peers by the Imperial command. During the Meiji period, this upper house of the Imperial Diet was modeled on the British House of Lords. 
102 The ironclad "Floriano" undertook her last assignment in the rivers of the Amazon in 1931, and was decommissioned in 1934

${ }^{103}$ He was survived by his wife May Iris Mayeda and his adoptive daughter Celeste Iris Mayeda. Belém’s newspapers gave considerable space to news of Mayeda's funeral in 1941. The newspapers provided a short biography highlighting his role in the project of Japanese immigration and his position on the council of Nankatu Co. O Estado do Pará,, Belém, 11/29/1941, Folha do Norte, Belém, 11/29/1941. 